\title{
KADAR PROTEIN KASAR DAN FERMENTABILITAS SECARA IN VITRO JERAMI TANAMAN KEDELAI YANG DITANAM DENGAN PENYIRAMAN AIR LAUT DAN MULSA ECENG GONDOK
}

\author{
A. Fauzi $^{1}$, Surahmanto ${ }^{2}$ dan A. Darmawati ${ }^{2}$ \\ 1) Mahasiswa Fakultas Peternakan Dan Pertanian Universitas Diponegoro \\ Kampus drh. Soejono Koesoemowardojo Tembalang Semarang 50275 \\ E-mail: fafnan87@yahoo.com \\ ${ }^{2)}$ Fakultas Peternakan dan Pertanian, Universitas Diponegoro \\ Kampus drh. R. Soejono Kusumowardojo Tembalang, Semarang 50275 \\ Diterima: 04 Pebruari 2016 Disetujui: 07 Oktober 2016
}

\begin{abstract}
ABSTRAK
Penelitian ini bertujuan untuk mengkaji kadar protein kasar, produksi volatile fatty acids (VFA) dan amonia $\left(\mathrm{NH}_{3}\right)$ secara in vitro jerami kedelai yang ditanam dengan perlakuan penyiraman air laut dan mulsa eceng gondok. Penelitian menggunakan Rancangan Acak Lengkap Pola Faktorial 4x2 dengan 4 ulangan. Faktor pertama adalah level penyiraman air laut yang terdiri dari L0 (tanpa air laut/air tawar), L1 (air laut EC 1 mmhos/cm), L2 (air laut EC 1,5 mmhos/cm), dan L3 (air laut EC $2 \mathrm{mmhos} / \mathrm{cm}$ ). Faktor kedua adalah pemberian dosis mulsa eceng gondok yang terdiri dari M1 (tanpa mulsa) dan M2 (mulsa eceng gondok dosis 4 ton/ha), Data dianalisis ragam (ANOVA) dan untuk mengetahui perbedaan antar perlakuan dilanjutkan dengan uji Duncan. Hasil penelitian menunjukkan bahwa tidak terdapat pengaruh interaksi yang nyata terhadap kadar protein kasar. Data produksi VFA dan $\mathrm{NH}_{3}$ menunjukkan ada pengaruh yang nyata $(\mathrm{P}<0,05)$ dengan level penyiraman air laut, tetapi pada perlakuan pemberian mulsa menunjukkan tidak ada pengaruh yang nyata $(\mathrm{P}>0,05)$ dan juga tidak ada interaksi antara kedua perlakuan tersebut. Kesimpulan penelitian ini adalah perlakuan penyiraman level air laut menurunkan nilai kadar protein kasar tetapi perlakuan tersebut dapat menaikkan nilai produksi VFA dan $\mathrm{NH}_{3}$. Perlakuan pemberian mulsa eceng gondok menurunkan nilai kadar protein kasar dan produksi $\mathrm{NH}_{3}$ tetapi perlakuan tersebut menaikkan produksi VFA.
\end{abstract}

Kata kunci: Jerami kedelai, air laut, mulsa eceng gondok, fermentabilitas, in vitro.

\section{CRUDE PROTEIN CONTENT AND IN VITRO FERMENTABILITY OF SOYBEAN STRA W PLANTED IN WATERING SEA WATER TREATMENT AND WATER HYACINTH MULCH}

\begin{abstract}
The aim of the experiment was to evaluated the levels of crude protein, production of volatyl vaty acid and ammonia (NH3) of soyabean straw, that planted with enceng gondok mulcing and watering with sea water. The research was arranged in a completely randomized design, consisted of 2 factor. The first factor was the level of sea water sprinkling; LO (without sea water; used original water); L1 (sea water EC 1 mmhos/cm),
\end{abstract}


L2 (sea water EC $1.5 \mathrm{mmhos} / \mathrm{cm}$ ), and L3 (sea water EC $2 \mathrm{mmhos} / \mathrm{cm}$ ). The second factor was the dose of mulch hyacinth which consists of $M 1$ (without mulch) and $M_{2}$ (4 tons/ha mulch), analysis of variance (ANOVA) and to know the difference between treatments then continued with Duncan test. The results showed there is that there is no significant interaction effect on levels of crude protein. VFA and $\mathrm{NH}_{3}$ production data showed no significant effect $(P<0.05)$ with a sprinkling of sea water level but at mulching treatment showed no significant effect $(P>0.05)$ and also no interaction between the two treatments. The conclusion of this study stated that the treatment of sea water level watering down the value of the levels of crude protein but such treatment may increase the value of production of VFA and $\mathrm{NH}_{3}$. Hyacinth mulching treatment decreased the value and production levels of crude protein and $\mathrm{NH}_{3}$ but such treatment raised VFA production.

Keywords: soybean straw, sea water, mulch hyacinth, fermentability, in vitro.

\section{PENDAHULUAN}

Pakan adalah suatu bahan yang dimakan hewan atau ternak dan mengandung nutrien yang dibutuhkan oleh ternak serta tidak membahayakan untuk ternak. Hijauan pakan, merupakan pakan utama bagi ruminansia, namun ketersediaannya sangat terbatas sehingga merupakan problem yang belum dapat diatasi hingga saat ini. Hal ini memberikan peluang memanfaatkan limbah pertanian seperti jerami kedelai sebagai pakan alternatif. Limbah pertanian mempunyai kualitas yang rendah, karena kandungan serat kasar tinggi (selulosa, hemiselulosa, lignin), sehingga mempunyai nilai kecernaan yang rendah bila dibandingkan dengan hijauan segar .

Kedelai merupakan komoditas pertanian yang sangat dibutuhkan di Indonesia, karena dapat dikonsumsi dalam berbagai produk makanan olahan seperti tahu, tempe, dan masih banyak produk olahan lainnya. Menurut Dudik (2015) kebutuhan kedelai Indonesia di tahun 2013 sekitar 2,2 juta ton. Produksi kedelai nasional hanya mampu memasok sekitar 0,8 juta ton. Sisanya 1,4 juta ton kedelai atau sekitar $70 \%$ dari kebutuhan kedelai nasional, harus dipenuhi dari impor. Selain untuk pakan ternak, kedelai juga digunakan sebagai bahan baku industri. Direktorat gizi Departemen Kesehatan RI (1996) menyatakan kandungan gizi kedelai cukup tinggi antara lain mengandung 34,90 gram protein, 34,80 gram karbohidrat dan 18,10 gram lemak.

Air laut mempunyai kandungan mineral yang tinggi, khususnya unsur-unsur yang dibutuhkan tanaman seperti magnesium $(\mathrm{Mg})$, kalsium $(\mathrm{Ca})$ dan kalium (K) menunjukkan bahwa air laut dapat menjadi salah satu sumber alternatif mineral bagi tanaman (Reddy dan Iyengar, 1999 yang disitasi oleh Yufdy dan Jumberi, 2010).

Pertumbuhan gulma air eceng gondok sangat cepat dan mengganggu fungsi perairan. Upaya pemanfaatan eceng gondok yaitu dengan menjadikannya sebagai mulsa atau sersah menjadi salah satu pilihan untuk pemanfaatan gulma eceng gondok.

Jerami kedelai merupakan limbah pertanian yang umumnya mempunyai kualitas protein dan kecernaannya rendah akan tetapi memiliki kandungan serat yang tinggi. Jerami kedelai memiliki kandungan BK (\%) 90,88, PK (\% BK) 8,35, SK (\% BK) 40,82, TDN (\% BK) 52,98 (Hudhia dan Uum, 2006). 
Penelitian ini bertujuan untuk mengkaji kadar protein kasar, produksi volatile fatty acids dan amonia rumen secara in vitro jerami tanaman kedelai. Manfaat yang bisa diambil adalah dapat memberikan informasi ilmiah mengenai kualitas jerami tanaman kedelai ditinjau dari kadar protein kasar, volatile fatty acids dan amonia in vitro dengan menggunakan penyiraman air laut dan mulsa eceng gondok.

\section{MATERI DAN METODE}

\section{Waktu dan Lokasi Penelitian}

Penelitian dilaksanakan pada bulan Agustus 2014 sampai Februari 2015 di Rumah Kaca. Penelitian secara Laboratoris di Laboratorium Ilmu Nutrisi Pakan, Laboratorium Fisiologi dan Pemuliaan Tanaman, dan Laboratorium Ekologi dan Produksi Tanaman, Fakultas Peternakan dan Pertanian, Universitas Diponegoro, Semarang.

\section{Materi Penelitian}

Bahan yang digunakan dalam penelitian ini yaitu benih kedelai, air laut yang diambil dari Pantai Marina Semarang sebagai penyiraman, tanah $11 \mathrm{~kg}$ per polybag, air, mulsa eceng gondok, pupuk (N, P dan K), jerami kedelai yang telah dipanen sebagai analisis untuk uji kadar protein kasar dan fermentabilitas secara in vitro, bahan untuk analisis protein kasar, fermentasi, produksi VFA dan produksi $\mathrm{NH}_{3}$. Alat yang digunakan adalah 4 ember ukuran 30 liter, 32 polybag ukuran $25 \mathrm{~cm} \mathrm{x}$ $35 \mathrm{~cm}$, plastik, EC (Electrical Conductivity) meter, cangkul, gunting, termohigro, selang, timbangan, pita ukur, timbangan analitis, pisau, gunting, alat untuk analisis protein kasar, fermentasi, produksi VFA dan produksi $\mathrm{NH}_{3}$.

\section{Metode Penelitian}

Penelitian ini menggunakan rancangan percobaan Rancangan Acak Lengkap Pola Faktorial $4 \times 2$ dengan 4 ulangan. Faktor pertama adalah level salinitas air laut meliputi: L0 = tanpa air laut (air tawar); $\mathrm{L} 1=$ air laut EC 1 mmhos/cm; L2 = air laut $\mathrm{EC} 1,5$ mmhos/cm; L3 = air laut EC 2 mmhos $/ \mathrm{cm}$. Faktor kedua adalah dosis mulsa eceng gondok meliputi: $\mathrm{M} 1=$ tanpa mulsa; $\mathrm{M} 2=$ mulsa eceng gondok dosis 4 ton/ha.

Prosedur penelitian meliputi tahap persiapan penelitian, tahap pelaksanaan penanaman kedelai, dan tahap analisis jerami kedelai di laboratorium. Penelitian dilaksanakan dengan model penelitan di green house dan laboratorium.

\section{Tahap Persiapan Penelitian}

Sebanyak 32 polybag diisi tanah sampai siap ditanami. Benih kedelai yang baik dipilih dan disiapkan. Pupuk dasar yang digunakan adalah pupuk N, P, K masing-masing dengan dosis $100 \mathrm{~kg} \mathrm{~N} / \mathrm{ha}$, $150 \mathrm{~kg} \mathrm{P}_{2} \mathrm{O}_{5} / \mathrm{ha}$ dan $100 \mathrm{~kg} \mathrm{~K}_{2} \mathrm{O} / \mathrm{ha}$. Air laut yang digunakan untuk penyiraman dengan dosis pengenceran sesuai dengan perlakuan. Mulsa eceng gondok dikeringkan dan diberikan dalam masing-masing polybag. Eceng gondok yang digunakan diambil dari daerah Banyumanik Semarang, dipotongpotong sekitar 1-2 $\mathrm{cm}$. Eceng gondok yang digunakan sesuai dengan dosis perlakuan yang diberikan.

\section{Tahap pelaksanaan penelitian}

Tahap pelaksanaan dilakukan dengan kegiatan pemberian mulsa eceng gondok pada polybag sesuai perlakuan, penanaman kedelai dilakukan dengan memberikan 7 benih per polybag yang nantinya disisakan 3 tanaman per polybag. Pemberian pupuk N, P, K. Pupuk N diberikan 3 kali yaitu 1/3 
dosis pada saat awal tanam, 1/3 dosis saat tanaman kedelai mulai berbunga umur 5 minggu dan $1 / 3$ dosis pada saat tanaman kedelai mulai tumbuh buah umur 7 minggu. Penyiraman dilakukan setiap hari dengan air tawar dan dengan air laut yang telah diencerkan sesuai perlakuan 1, 1,5 dan 2 mmhos $/ \mathrm{cm}$ sebanyak $500 \mathrm{ml} /$ pot. Setelah panen jerami di potong dan di jemur 2-3 hari, kemudian digiling sampai halus dan dianalisis.

\section{Analisis Jerami Kedelai}

Tahap analisis dilakukan dengan analisis kadar protein kasar, produksi VFA dan $\mathrm{NH}_{3}$ rumen secara in vitro yang dilakukan di Laboratorium Ilmu Nutrisi Pakan, Fakultas Peternakan dan Pertanian, Universitas Diponegoro. Parameter yang diamati meliputi kadar serat kasar dan kecernaan bahan kering dan bahan organik jerami kedelai secara in vitro. Data dianalisis ragam (ANOVA) dan untuk mengetahui perbedaan antar perlakuan dilanjutkan dengan Uji Beda Wilayah Berganda Duncan.

\section{HASIL DAN PEMBAHASAN}

Keseluruhan hasil penelitian yang meliputi kadar proein kasar, produksi VFA dan produksi $\mathrm{NH}_{3}$ rumen disajikan pada Tabel 1.

Tabel 1. Rangkuman Hasil Rata-Rata Kadar Protein Kasar, Produksi VFA dan $\mathrm{NH}_{3}$ rumen Jerami Tanaman Kedelai secara In Vitro

\begin{tabular}{ccccc}
\hline & \multicolumn{4}{c}{ Perlakuan Penyiraman Air Laut } \\
\cline { 2 - 5 } & L0 & L1 & L2 & L3 \\
\hline PK & $8,56^{\mathrm{a}}$ & $8,27^{\mathrm{a}}$ & $8,08^{\mathrm{a}}$ & $8,50^{\mathrm{a}}$ \\
VFA & $100^{\mathrm{ab}}$ & $104,3^{\mathrm{b}}$ & $105,9^{\mathrm{b}}$ & $117,8^{\mathrm{a}}$ \\
$\mathrm{NH}_{3}$ & $6,47^{\mathrm{b}}$ & $6,58^{\mathrm{b}}$ & $7,52^{\mathrm{a}}$ & $7,58^{\mathrm{a}}$ \\
\hline a, b Superskrip yang berbeda pada baris yang sama menunjukkan perbedaan yang nyata \\
$(\mathrm{P}<0,05)$.
\end{tabular}

\section{Kadar Protein Kasar}

Persentase rata-rata kadar protein kasar jerami kedelai (Tabel 2) tanpa penyiraman air laut (L0), penyiraman air laut $1 \mathrm{mmhos} / \mathrm{cm}$ (L1), penyiraman air laut 1,5 mmhos/cm (L2), dan penyiraman air laut $2 \mathrm{mmhos} / \mathrm{cm}$ (L3) secara berturut-turut sebesar 8,56, 8,27, 8,08, dan 8,50\%. Hal ini menunjukan bahwa pada perlakuan penyiraman air laut belum mampu menaikan kadar protein kasar jerami tanaman kedelai. Hal tersebut dikarenakan kandungan hara air laut yang tinggi diantaranya magnesium $(\mathrm{Mg})$, kalsium $(\mathrm{Ca})$ dan kalium (K). Unsur hara tersebut bagi tanaman kedelai salah satunya berfungsi merangsang pembentukan biji, sehingga tanaman cepat mengalami fase generatif, sehingga protein kasarnya semakin berkurang. Hal ini sesuai dengan pendapat Lingga dan Marsono (2009) fungsi kalsium (Ca) adalah memperkeras batang tanaman dan sekaligus merangsang pembentukan biji, sedangkan magnesium (Mg) merupakan bagian tanaman dari klorofil dan berperan dalam pembentukan buah. Menurut Tillman et al. (1998) semakin tua suatu tanaman kadar protein akan semakin berkurang disebabkan rasio daun dan batang berkurang.

Rata-rata kadar protein kasar pada perlakuan tanpa pemberian mulsa eceng gondok (M1) sebesar 8,60\% dan dengan pemberian mulsa eceng gondok 4 ton/ha 
(M2) sebesar $8,11 \%$. Hal ini menunjukkan bahwa pada penanaman kedelai dengan perlakuan mulsa eceng gondok 4 ton/ha belum mampu menaikan kadar protein kasar jerami tanaman kedelai. Hal ini dikarenakan rentang waktu pemberian mulsa eceng gondok dengan penanaman sama sehingga mulsa eceng gondok belum mengalami proses dekomposisi, sehingga fungsi pemulsaan untuk memperbaiki sifat fisik dan kimia tanah belum berjalan dengan sempurna. Menurut Purwowidodo (1983) disitasi Junaidi et al., (2013), beberapa kelebihan pemberian mulsa antara lain melindungi agregat - agregat tanah, meningkatkan penyerapan air oleh tanah, mengurangi volume dan kecepatan aliran permukaan, konservasi air karena mulsa mengurangi evaporasi, memelihara kandungan bahan organik tanah dan mengendalikan pertumbuhan gulma.

\section{Produksi Volatile Fatty Acids (VFA)}

Perlakuan penyiraman air laut, tanpa penyiraman air laut (L0), penyiraman air laut $1 \mathrm{mmhos} / \mathrm{cm}$ (L1), penyiraman air laut 1,5 $\mathrm{mmhos} / \mathrm{cm}$ (L2), dan penyiraman air laut $2 \mathrm{mmhos} / \mathrm{cm}$ (L3). Hal ini menunjukkan bahwa penyiraman air laut mampu meningkatkan degradabilitas bahan organik jerami tanaman kedelai sehingga produksi VFA jerami meningkat karena VFA merupakan hasil dari proses degradasi bahan organik. Hal ini sesuai dengan Sutardi et al. (1983) bahwa konsentrasi VFA optimal yang dibutuhkan untuk pertumbuhan mikrobia adalah $80-160 \mathrm{mM}$. Konsentrasi VFA (volatile fatty acids) dalam cairan rumen berhubungan erat dengan fermentabilitas, jenis dan kualitas bahan dari ransum yang difermentasi oleh mikrobia rumen (Tillman et al., 1998).

Produksi VFA jerami tanaman kedelai dengan perlakuan penyiraman air laut 1, 1,5 dan $2 \mathrm{mmhos} / \mathrm{cm}$ mengalami peningkatan yaitu $\mathrm{L} 0=100 ; \quad \mathrm{L} 1=104,37$; L2=105,93 dan L3=117,81. Hal tersebut di duga karena kandungan mineral $\mathrm{Na}, \mathrm{Cl}, \mathrm{K}$, $\mathrm{Ca}$ dan $\mathrm{Mg}$ yang ada pada jerami tanaman berperan sebagai nutrien bagi mikrobia rumen sehingga mempengaruhi produksi VFA. Hal ini sesuai dengan pendapat Yufdy dan Jumberi (2010) bahwa air laut dapat digunakan sebagai sumber hara bagi tanaman karena kandungan $\mathrm{Na}, \mathrm{K}, \mathrm{Ca}$, dan $\mathrm{Mg}$ yang tinggi. Menurut Rahmadi et al. (2003) bahwa mineral magnesium ( $\mathrm{Mg}$ ), kalsium $(\mathrm{Ca})$, kalium $(\mathrm{K})$, natrium atau sodium $(\mathrm{Na})$, fosfat $\left(\mathrm{PO}_{4}\right)$ dan sulfur $(\mathrm{S})$ merupakan kebutuhan umum bagi mikrobia rumen. Peningkatkan VFA juga disebabkan karena degradabilitas bahan organik jerami tanaman kedelai meningkat (Lampiran 12). Hal ini sesuai dengan Tanuwiria et al. (2005) bahwa produksi VFA total mencerminkan banyaknya bahan organik ransum yang dapat didegradasi oleh mikrobia rumen.

\section{Produksi Amonia ( $\left.\mathbf{N H}_{3}\right)$}

Hasil uji wilayah ganda Duncan menunjukkan bahwa produksi $\mathrm{NH}_{3}$ memperlihatkan perbedaan nyata pada perlakuan penyiraman air laut, tanpa penyiraman air laut (L0), penyiraman air laut $1 \mathrm{mmhos} / \mathrm{cm}$ (L1), penyiraman air laut $1,5 \mathrm{mmhos} / \mathrm{cm}$ (L2), dan penyiraman air laut $2 \mathrm{mmhos} / \mathrm{cm}$ (L3). Produksi $\mathrm{NH}_{3}$ rumen meningkat disebabkan oleh degradasi kadar protein kasar didalam rumen oleh mikrobia menjadi peptida yang selanjutnya didegradasi menjadi asam amino. Asam amino oleh mikrobia rumen akan didegradasi lebih lanjut menjadi amonia asam-asam organik dan $\mathrm{CO}_{2}$. Tillman et al. (1998) meyatakan bahwa produksi amonia rumen dipengaruhi oleh sumber nitrogen, kelarutan dan 
degradabilitas protein, sumber energi, dan absorbsi amonia.

Tanaman kedelai yang diberi perlakuan penyiraman air laut 1, 1,5 dan 2 mmhos/cm diduga meningkatkan produksi $\mathrm{NH}_{3}$ jerami tanaman yang mengandung mineral $\mathrm{Na}, \mathrm{Cl}, \mathrm{K}, \mathrm{Ca}$ dan $\mathrm{Mg}$ yang berperan sebagai nutrien bagi mikrobia rumen. Hal ini sesuai dengan pendapat Yufdy dan Jumberi (2010) bahwa air laut dapat digunakan sebagai sumber hara bagi tanaman karena kandungan $\mathrm{Na}, \mathrm{K}, \mathrm{Ca}$, dan $\mathrm{Mg}$ yang tinggi. Menurut Rahmadi et al. (2003) bahwa mineral magnesium ( $\mathrm{Mg})$, kalsium (Ca), kalium (K), natrium atau sodium $(\mathrm{Na})$, fosfat $\left(\mathrm{PO}_{4}\right)$ dan sulfur $(\mathrm{S})$ merupakan kebutuhan umum bagi mikrobia rumen. Peningkatan mikrobia rumen dan kebutuhan mikrobia rumen terpenuhi menyebabkan degradasi protein meningkat, sehingga terjadi peningkatan produksi $\mathrm{NH}_{3}$. Arora (1995) menyatakan bahwa faktorfaktor yang mempengaruhi konsentrasi $\mathrm{N}$ $\mathrm{NH}_{3}$ antara lain: (1) sumber protein ransum sangat tahan degradasi mikrobia rumen, (2) tingginya sintesis protein mikrobia sehingga sisa $\mathrm{N}_{-} \mathrm{NH}_{3}$ yang tidak dimanfaatkan akan semakin kecil, (3) rendahnya taraf energi pakan, (4) nisbah $\mathrm{C}$ dan $\mathrm{N}$ serta (5) rendahnya pertumbuhan mikrobia.

\section{SIMPULAN DAN SARAN Simpulan}

Berdasarkan hasil penelitian disimpulkan bahwa Kombinasi perlakuan penyiraman air laut dan pemberian mulsa eceng gondok secara bersama-sama belum memberikan peningkatan kadar protein kasar. perlakuan penyiraman level air laut tidak berpengaruh nyata terhadap kadar protein kasar tetapi berpengaruh nyata terhadap produksi VFA dan $\mathrm{NH}_{3}$. Perlakuan pemberian mulsa eceng gondok tidak berpengaruh nyata terhadap kadar protein kasar dan produksi $\mathrm{NH}_{3}$ tetapi menaikan produksi VFA.

\section{Saran}

Saran yang diberikan berdasarkan hasil penelitian lebih lanjut dengan peningkatan dosis mulsa dan rentang waktu pemberian mulsa pada waktu sebelum penanaman, sehingga memberi kesempatan mulsa eceng gondok untuk terdekomposisi sehingga dapat memperbaiki sifat fisik, biologi dan kimia tanah. Perlunya penggunaan penyiraman air laut untuk penaman kedelai dilahan pertanian Indonesia dan air laut dapat menjadi alternatif penggunaan pupuk. Selain itu jeraminya dapat menjadi pakan alternatif bagi ternak ruminansia.

\section{DAFTAR PUSTAKA}

Arora, S.P. 1995. Pencernaan Mikroba pada Ruminansia. Gadjah Mada University Press. Yogyakarta. (Diterjemahkan oleh Retno Murwani dan Editor Bambang Srigandono).

Direktorat Gizi Depkes RI, 1996. Daftar Komposisi Bahan Makanan. Bhratara Karya Aksara, Jakarta.

Dudik Harnowo, 2015. https://ugm.ac.id /id/berita/9987-produksi.kedelai. nasional. masih.rendah . Diakses tanggal 07 Mei 2015.

Hudhia, N. K Dan Uum U. 2006. Identifikasi dan evaluasi kandungan nutrisi Istimewa Yogyakarta. Prosiding. Seminar Nasional Teknologi Peternakan Dan Veteriner 2006. 
Junaidi Imam., Sartono Joko Santosa, dan Endang S.S. 2013. Pengaruh macam mulsa dan pemangkasan terhadap pertumbuhan dan hasil tanaman semangka (Citrullus vulgaris schard), Fakultas Pertanian Unisri Surakarta, Jurnal Inovasi Pertanian Vol. 12, No. 2.

Lingga, P. dan Marsono. 2009. Petunjuk Penggunaan Pupuk. Penebar Swadaya, Depok

Purwowidodo. 1983. Teknologi Mulsa. Dewaruci Press, Jakarta.

Rahmadi, D., Sunarso, J. Achmadi, A. Muktiani, M. Christiyanto dan Surono. 2003. Ruminologi Dasar. Jurusan Nutrisi dan Makanan Ternak Fakultas Peternakan Universitas Diponegoro, Semarang.

Sutardi, T., N. A. Sigit dan T. Toharmat. 1983. Standarisasi Mutu Protein Bahan Makanan Ternak Ruminansia, Berdasarkan Parameter Metabolismenya oleh Mikrobia Rumen. Proyek Pengembangan Ilmu dan Teknologi. Ditjen Pendidikan Tinggi, Jakarta.

Tanuwiria, U. H., Ayuningsih Budi dan Mansyur. 2005. Fermentabilitas dan kecernaan ransum lengkap sapi perah berbasis jerami padi dan pucuk tebu teramoniasi (in vitro). Jurnal Ilmu Ternak, Vol. 5 (2): 6469.

Tillman, A. D., H. Hartadi, S. Reksohadiprojo, S. Prawirokusumo, dan S. Lebdosoekojo. 1998. Ilmu Makanan Ternak Dasar. Edisi 6. Gadjah Mada University Press, Yogyakarta.
Yufdy, M.P dan A. Jumberi. 2010. Pemanfaatan hara air laut untuk memenuhi kebutuhan tanaman. Balai Pengkajian Teknologi Pertanian Sumatra Utara dan Balai Penelitian Lahan Rawa Banjar Baru, Sumatra Utara. 